\title{
PENINGKATAN HASIL BELAJAR IPS DENGAN METODE ROLE PLAYING PADA SISWA KELAS III DI SDN O27 SAMARINDA ULU
}

\author{
Gamar Al Haddar, Marjulianti \\ Universitas Widya Gama Mahakam Samarinda \\ gamar@uwgm.ac.id, marjuliantiuli@gmail.com
}

\begin{abstract}
ABSTRAK
Penelitian ini bertujuan untuk mengetahui peningkatan hasil belajar dengan menerapkan metode pembelajaran Role Playing dalam pembelajaran IPS pada siswa kelas III SDN 027 Samarinda Ulu. Jenis penelitian ini adalah Penelitian Tindakan Kelas. Penelitian Tindakan Kelas di laksanakan tiga siklus. Setiap siklus tiga kali pertemuan. Subjek penelitian adalah siswa yang berjumlah 31 siswa, 21 laki-laki dan 10 perempuan. Instrumen yang digunakan dalam penelitian ini adalah lembar observasi, lembar wawancara, tes hasil belajar, dan dokumentasi. Kemudian data yang telah diperoleh dianalisis dengan menggunakan metode peneltian Mixed Methods. Berdasarkan Penelitian Tindakan Kelas Pada hasil observasi aktivitas siswa pada siklus I perhatian siswa $66 \%$, keaktifan $59 \%$, kerjasama $60 \%$, pemahaman $66 \%$. Siklus II perhatian 70\%, keaktifan siswa $74 \%$, kerjasama siswa $72 \%$, pemahaman $73 \%$. Pada siklus III perhatian siswa 91\%, keaktifan siswa 91\% kerjasama 90\%, pemahaman siswa $91 \%$. Hasil wawancara pada siklus I, II, dan III peneliti mewawancarai 20 orang siswa dan hasil persentase yang menyukai pembelajaran dengan menggunakan metode Role Playing yaitu $100 \%$. Berdasarkan prasiklus nilai tes belajar siswa dengan nilai rata-rata 61 dengan nilai persentase $40 \%$ dan pada siklus I yang tuntas 15 orang dengan persentase ketuntasan $48,38 \%$ dan meningkat pada siklus II yang tuntas 20 orang dengan persentase $64,51 \%$ dan kembali meningkat lagi pada siklus III yang tuntas 31 orang dengan persentase $100 \%$. Berdasarkan hasil penelitian yang dilakukan, dapat disimpulkan bahwa metode Role Playing dapat meningkatkan hasil belajar mata pelajaran IPS pada siswa kelas III SDN 027 Samarinda Ulu.
\end{abstract}

Kata kunci: Role Playing \& Hasil Belajar IPS

\begin{abstract}
This study aims to determine the improvement of learning outcomes by implementing Role Playing learning methods for learning IPS in class III students at SDN 027 Samarinda Ulu. This type of research is class action research. Class action research performs three cycles. Each cycle three times the meeting. The research subject is a student of 31 students, 21 males and 10 females. The instruments used in this study are observation sheets, interview sheets, study results tests, and documentation. Then the data that has been obtained is analyzed using the study method Mixed Methods. Based on class action research on the results of the observation of students in the cycle I attentiveness $66 \%$, the activity of $59 \%$, cooperation $60 \%$, understanding $66 \%$. Cycle II attention $70 \%$, activity students $74 \%$, student cooperation $72 \%$, understanding $73 \%$. On the III cycle of the student's attention is $91 \%$, student activity $91 \%$ cooperation 90\%, students ' understanding 91\%. The interview results in Cycles I, II, and III researchers interviewed 20 students and the percentage results that love learning using the Role Playing method is $100 \%$. Based on the students 'study test value with an average rating of 61 with a percentage value of $40 \%$ and in the cycle I completed 15 people with a percentage of the compensation of $48.38 \%$ and increased in cycle II that completed 20 people with a percentage of $64.51 \%$ and returned Cycle of 31 people with a percentage of $100 \%$. Based on the results of the study, it can be concluded that the Role Playing method can improve the learning outcomes of IPS in grade III students at SDN 027 Samarinda Ulu.
\end{abstract}

Keywords: Role Playing \& Learning Results IPS 


\section{PENDAHULUAN}

Pendidikan adalah suatu usaha untuk menciptakan suasana belajar dan proses pembelajaran peserta didik yang awalnya tidak tahu menjadi tahu, dari tidak paham menjadi paham. Pendidikan itu bisa didapatkan dimana saja akan tetapi yang harus diperhatikan adalah bagaimana memberikan pendidikan dengan baik dan benar, agar peserta didik tidak terjerumus dalam kehidupan yang negatif. Pendidikan mempunyai peranan penting bagi kelangsungan hidup negara, karena pendidikan merupakan sarana untuk meningkatkan serta memperluas kualitas sumber daya manusia. dengan demikian adanya pendidikan kehidupan manusia menjadi terarah.

Salah satu tujuan sekolah adalah untuk membentuk konsep berfikir siswa sehingga mampu mengembangkan kreativitas dan segenap kemampuan yang dimiliki sebagai bekal untuk dapat memecahkan setiap permasalahan yang dihadapi dalam kehidupan sehari-sehari. Selain itu, untuk membentuk siswa yang bertakwa dan bertanggung jawab atas dirinya sendiri dan lingkungan hidupnya. Dengan demikian peran sekolah sangatlah penting. sekolah dasar adalah tempat diamana siswa dapat menimbah ilmu, sekolah merupakan pendidikan formal yang telah disediakan oleh pemerintah untuk membuat para generasi mudah Indonesia menjadi cerdas dan berahklak mulia dan menjunjung tinggi arti pendidikan.

Guru adalah seorang pengajar yang tujuan utamanya untuk mendidik, mengajar, membimbing, mengarahkan, menilai dan mengevaluasi siswa. Siswa merupakan seorang pelajar yang dimana pada saat guru mengajar tugas utama siswa yaitu memperhatikan, menerima dan mengaplikasikan hasil dari yang telah dipelajarinya pada kehidupan sehariharinya. Sedangkan model, metode, alat peraga dan ruangan kelas merupakan suatu kebutuhan siwa dan guru untuk mendapatkan ilmu. Tanpa adanya model, metode, alat peraga dan ruangan kelas, maka proses belajar mengajar tidak akan efektif.

Dalam kehidupan masyarakat, Ilmu Pengetahuan Sosial (IPS) sangat penting perannya. Oleh karena itu, belajar IPS selayaknya merupakan kebutuhan dan menjadikan kegiatan belajar yang menyenangkan. tujuan mempelajari IPS agar siswa memiliki kemampuan di bidang sosial. Penanaman konsep IPS sangat diperlukan pada siswa, karena hal itu akan dapat diterapkan dalam kehidupan seharihari. IPS mengkaji seperangkat peristiwa fakta, konsep, dan yang berkaitan dengan isu sosial. Melalui mata pelajaran IPS, siswa diarahkan untuk dapat menjadi warga negara Indonesia yang demokratis, bertanggung jawab, serta warga yang cinta damai.

Proses pembelajaran yang optimal bagi peserta didik melibatkan metode pembelajaran sebagai sarana yang dimanfaatkan oleh guru untuk menyampaikan materi pembelajaran. Guru yang menghendaki peserta didiknya agar dapat memahami materi yang diajarkan secara optimal dan berusaha menggunakan metode pembelajaran seoptimal mungkin.

Metode pembelajaran merupakan suatu cara yang digunakan pengajar dalam menyajikan materi agar tujuan pembelajaran tercapai. Guru akan mengalami kesulitan tertentu jika materi pembelajaran tidak disampaikan dengan metode pembelajaran yang tepat, terutama jika materi pembelajaran tersebut menuntut peserta didik untuk terlibat secara langsung dalam materi pembelajaran yang disampaikan.

Berdasarkan observasi awal ditemukan bahwa siswa kurang aktif selama proses pembelajaran di kelas. Hal ini terbukti pada data nilai siswa yang mencapai KKM 40\% sedangkan yang tidak mencapai KKM adalah $60 \%$. Dengan demikian peneliti tertarik meneliti tentang peningkatan hasil belajar IPS dengan menggunakan metode Role Playing.

Metode pembelajaran Role Playing merupakan pembelajaran yang dilakukan oleh siswa dengan bermain peran. Kelas dapat diibaratkan sebagai suatu kehidupan masyarakat sosial tempat para siswa belajar mengemukakan pendapat dan saling menghargai. Berdasarkan latar belakang tersebut peneliti telah melaksanakan penelitian dengan mengambil judul Peningkatan Hasil Belajar IPS Melalui Metode Role Playing pada Siswa Kelas III 
C di SDN 027 Samarinda Ulu Tahun Pembelajaran 2018/2019.

\section{METODE PENELITIAN}

Penelitian yang digunakan yakni jenis penelitian ini adalah penelitian tindakan kelas. Menurut Arikunto (2010) penelitian tindakan kelas adalah pencermatan terhadap kegiatan belajar berupa sebuah tindakan yang sengaja dimunculkan dan terjadi dalam kelas secara bersama. Ada 4 tahapan dalam penelitian tindakan kelas yakni perencanaan, pelaksanaan, observasi dan refleksi.

Penelitian ini dilaksanakan di SDN 027 Samarinda Ulu yang beralamat di Jalan Pramuka Kelurahan Gunung Kelua Tahun Pembelajaran 2018/2019. Adapun waktu penelitian ini yakni bulan Maret sampai pada bulan April 2019. Subjek penelitian ini adalah siswa kelas III C di SDN 027 Samarinda Ulu dengan jumlah siswa 31 orang.

Instrumen penelitian berupa soal tes, lembar wawancara, lembar observasi dan kamera untuk dokumentasi. Adapun alat pengumpulan data yakni observasi, tes, wawancara dan dokumentasi. Prosedur penelitian akan dilaksanakan sebanyak tiga siklus masing-masing siklus dilaksanakan dua kali pertemuan menyampaikan materi dan pertemuan ke tiga memberikan tes.

Teknik analisis data yang digunakan peneliti dalam penelitian ini menggunakan metode Mixed Methods. Mixed Methods merupakan penelitian kombinasi atau menggabungkan antara metode kuantitatif dan metode kualitatif, jadi data yang dikumpulkan berupa data kuantitatif dan data kualitatif. Oleh karena itu teknik analisis data yang digunakan peneliti dalam penelitian ini adalah teknik analisis data kuantitatif dan kualitatif.

Jenis pendekatan yang digunakan dalam penelitian ini yakni penelitian kualitatif dan jenis analisis deskriptif yaitu berupa pemaparan dan bertujuan untuk memperoleh gambaran (deskripsi) lengkap mengenai bagaimana keadaan pembelajaran yang berkaitan dengan penerapan metode pembelajaran card sort. Pendekatan kualitatif dimaksudkan mengungkapkan gejala yang terjadi melalui pengumpulan data dari latar alami dengan memanfaatkan diri peneliti sebagai instrumen kunci.
Penelitian bersifat deskriptif dan cenderung menggunakan analisis dengan pendekatan induktif.

\section{TEMUAN PENELITIAN}

Pra siklus dilaksanakan pada hari kamis tanggal 7 maret 2019. Pra siklus ini dilakukan sebelum melaksanakan siklus 1 . Pada kegiatan pra siklus, peneliti melakukan pengamatan terhadap kegiatan pembelajaran IPS di Kelas III.

Hasil belajar IPS Kelas III prasiklus menunjukan bahwa nilai rata-ratanya adalah 60,80 Jumlah siswa yang mencapai kriteria ketuntasan minimal (KKM) yaitu 13 orang dengan persentase ketuntasan $40 \%$ dsiswa yang belum mencapai KKM yaitu 18 orang dengan persentase ketuntasan $60 \%$

\section{Hasil Penelitian Siklus I}

Siklus I tediri dari $3 \mathrm{x}$ pertemuan dalam kegiatan pembelajaran. Pada pertemuan pertama dan kedua adalah pelaksanaan kegiatan pembelajaran dengan menggunakan metode Role Playing materi mengenal jenis pekerjaan. Adapun tahapan penelitian sebagai berikut :

\section{1) Perencanaan}

Pada tahapan perencanaan pada siklus I peneliti menyusun serta mempersiapkan instrumen-instrumen penelitian, yaitu: Peneliti menyususn Rencana Pelaksanaan Pembelajaran (RPP) sesuai dengan materi dan metode yang digunakan yang diajarkan dan menyiapkan media pembelajaran serta peneliti juga menyiapkan lembar observasi untuk melihat proses pembelajaran selama pembelajaran berlangsung dan membuat lembar soal pembelajaran yang berupa tes tertulis.

\section{2) Pelaksanaan}

Pelaksanaan kegiatan belajar mengajar pada siklus I dilaksanakan tiga kali pertemuan yakni pada hari Jum'at tanggal 5 April 2019 pertemuan I, Sabtu, 6 April 2019 pada jam pertama pertemuan II, Selasa tanggal 9 April 2019 pertemuan III di kelas III C SDN 027 Samarinda Ulu.

Pertemuan I tanggal 5 April 2019 Pada kegiatan awal peneliti mengucapkan salam dan mengajak siswa berdoa menurut agama kepercayaan masing-masing dan setelah 
itu peneliti mengecek kehadiran siswa. Setelah itu peneliti menyampaikan judul materi dan tujuan pembelajaran yang akan dipelajari dan menjelaskan tentang metode Role Playing.

Pada kegiatan inti pertemuan I peneliti menjelaskan materi tentang mengenal jenis pekerjaan dan peneliti menyusun atau menyiapkan skenario yang akan ditampilkan dan menyampaikan materi pembelajaran setelah itu peneliti membagikan siswa dalam beberapa kelompok siswa diarahkan untuk bermain peran sesuai dengan perannya masing-masing dan setiap kelompok masing-masing memperhatikan dan mengamati skenario yang sedang dimainkan, Siswa memainkan perannya didepan kelas

Pada kegiatan akhir peneliti bersama siswa memberikan kesimpulan terhadap materi yang telah dipelajari dan mengakhiri pelajaran denggan berdoa menurut agama dan kepercayaan masing-masing serta mengucapkan salam.

Pertemuan II tanggal 6 april 2019 Pada kegiatan awal peneliti mengucapkan salam dan mengajak siswa berdoa menurut agama kepercayaan masing-masing dan setelah itu peneliti mengecek kehadiran siswa serta mengajak siswa melakukan yel-yel. Setelah itu peneliti menyampaikan judul materi dan tujuan pembelajaran yang akan dipelajari dan menjelaskan tentang metode Role Playing.

Pada kegiatan inti pertemuan II peneliti menjelaskan materi tentang mengenal jenis pekerjaan dan peneliti menyusun skenario yang akan ditampilkan dan menyampaikan materi pembelajaran setelah itu peneliti membagikan siswa dalam beberapa kelompok siswa diarahkan untuk bermain peran sesuai dengan perannya masing-masing dan setiap kelompok masing-masing memperhatikan dan mengamati skenario yang sedang dimainkan, Siswa memainkan perannya didepan kelas

Pada kegiatan akhir peneliti bersama siswa memberikan kesimpulan terhadap materi yang telah dipelajari dan mengakhiri pelajaran denggan berdoa menurut agama dan kepercayaan masing-masing serta mengucapkan salam.

Pertemuan III merupakan akhir dari siklus pertama, peneliti mengulang kembali sedikit dari materi yang diberikan peneliti pada pertemuan pertama dan kedua, tentang pengertian mengenal jenis pekerjaan, kemudian peneliti mengadakan tes tertulis yang akan diberikan kepada siswa. Soal yang digunakan pada tes tersebut berupa soal Isian. Pada saat tes berlangsung, siswa tidak diperbolehkan kerja sama. Hasil tes dikumpulkan kemudian peneliti bersama siswa membahas soal tes tersebut bersama-sama. Adapun hasil belajar IPS Kelas III C yang diperoleh dari siklus I menunjukan jumlah siswa yang tuntas sebanyak 15 siswa dengan persentase $48,38 \%$ dan siswa yang tidak tuntas sebanyak 16 siswa dengan persentase $51,61 \%$.

\section{3) Observasi}

Observasi ini dilaksanakan bersamaan dengan proses belajar mengajar pada siklus I. Adapun hasil yang diperoleh secara rinci dari setiap aspek penilaian yaitu: Pada siklus I pertemuan I siswa yang perhatian ketika proses pelajaran berlangsung mereka mendengarkan penjelasan guru yakni $57 \%$ dengan kategori cukup baik, siswa yang memiliki keaktifan seperti bertanya materi yang dijelaskan dan menjawab hasil pembelajaran, yakni $52 \%$ dengan kategori cukup baik, kemudian siswa yang bekerjasama dengan baik dalam bertukar pendapat dalam mengerjakan dan menjawab soal yakni $55 \%$ dengan kategori cukup baik, dan siswa yang memiliki pemahaman dalam menanggapi hasil pembelajaran yakni $61 \%$ dengan kategori baik. jadi perolehan persentase keseluruhan kelas aktivitas siswa yaitu $56 \%$.

Pada pertemuan II hasil yang diperoleh secara rinci dari setiap aspek penilaian yaitu siswa yang perhatian ketika proses pelajaran berlangsung mereka mendengarkan penjelasan guru yakni $75 \%$ dengan kategori baik, siswa yang memiliki keaktifan seperti bertanya tentang materi yang dijelaskan dan menjawab hasil pembelajaran yakni 
77\% dengan kategori baik, kemudian siswa yang bekerjasama dengan baik dalam bertukar pendapat dalam mengerjakan dan menjawab soal yakni $72 \%$ dengan kategori baik, dan siswa yang memiliki pemahaman dalam menanggapi hasil pembelajaran yakni $75 \%$ dengan kategori baik. jadi perolehan persentase keseluruhan kelas yaitu $69 \%$.

4) Refleksi

Berdasarkan hasil pembelajaran siklus I yang telah dilaksanakan dengan penerapan metode Role Playing Berdasarkan hasil tes belajar siswa ada 15 siswa yang mengalami ketuntasan dengan persentase $48,38 \%$ dan 16 siswa nya lagi mengalami ketidaktuntasan dengan persentase $51,61 \%$.

Berdasarkan hasil wawancara dengan 20 siswa hanya 9 siswa yang menyukai terkait dengan aspek siswa yang menyukai pelajaran IPS dengan menggunakan metode Role Playing dan 11 siswanya lagi tidak menyukai pelajaran IPS dengan menggunakan metode Role Playing. Siswa yang mengalami kesulitan saat belajar IPS dengan menggunakan metode Role Playing ada 19 siswa sedangkan 1 orrang siswanya lagi tidak mengalami kesulitan pada saat belajar IPS dengan menggunakan metode Role Playing. Siswa yang menyukai metode Role Playing ada 6 orang siswa sedangkan 14 siswanya lagi tidak menyukai metode Role Playing, dan siswa yang menyukai cara guru mengajar IPS ada 18 siswa sedangkan 2 siswanya lagi tidak menyukai cara guru mengajar IPS dikelas.

Berdasarkan hasil observasi selama proses pembelajaran berlangsung ternyata masih ada siswa yang kurang fokus, dan masih malu untuk bertanya. Berdasarkan hasil telaah di atas masih banyak yang harus diperbaiki dengan demikian maka peneliti memutuskan untuk melanjutkan pada siklus II.

\section{Hasil Penelitian Siklus II}

Siklus II tediri dari $3 \mathrm{x}$ pertemuan dalam kegiatan pembelajaran. Pada pertemuan pertama dan kedua adalah pelaksanaan kegiatan pembelajaran dengan menggunakan metode Role
Playing materi memahami pentingnya semangat kerja. Adapun tahapan pelaksanaanya sebagai berikut:

\section{1) Perencanaan}

Pada tahapan perencanaan pada siklus II peneliti menyusun serta mempersiapkan instrumen-instrumen penelitian, yaitu: Peneliti menyususn Rencana Pelaksanaan Pembelajaran (RPP) sesuai dengan materi dan metode yang digunakan yang diajarkan dan menyiapkan media pembelajaran serta peneliti juga menyiapkan lembar observasi untuk melihat proses pembelajaran selama pembelajaran berlangsung dan membuat lembar soal pembelajaran yang berupa tes tertulis.

\section{2) Pelaksanaan Tindakan}

Pelaksanaan kegiatan belajar mengajar pada siklus II dilaksanakan pada hari Kamis tanggal 11 April 2019 pertemuan I , Jum'at tanggal 12 April 2019 pada jam kedua pertemuan II jumlah, Sabtu tanggal 13 April 2019 pertemuan III di kelas III C SDN 027 Samarinda Ulu.

Pertemuan I tanggal 11 april 2019 Pada kegiatan awal peneliti mengucapkan salam dan mengajak siswa berdoa menurut agama kepercayaan masing-masing dan setelah itu peneliti mengecek kehadiran siswa. Setelah itu peneliti menyampaikan judul materi dan tujuan pembelajaran yang akan dipelajari dan menjelaskan tentang metode Role Playing.

Pada kegiatan inti di pertemuan I peneliti menjelaskan materi tentang memahami pentingnya semangat kerja dan peneliti menyusun atau menyiapkan skenario yang akan ditampilkan dan menyampaikan materi pembelajaran setelah itu peneliti membagikan siswa dalam beberapa kelompok Siswa diarahkan untuk bermain peran sesuai dengan perannya masing-masing dan setiap kelompok masing-masing memperhatikan dan mengamati skenario yang sedang di mainkan, Siswa memainkan perannya didepan kelas

Pada kegiatan akhir peneliti bersama siswa memberikan kesimpulan terhadap materi yang telah 
dipelajari dan mengakhiri pelajaran denggan berdoa menurut agama dan kepercayaan masing-masing serta mengucapkan salam.

Pertemuan II tanggal 12 april 2019 Pada kegiatan awal peneliti mengucapkan salam dan mengajak siswa berdoa menurut agama kepercayaan masing-masing dan setelah itu peneliti mengecek kehadiran siswa. Setelah itu peneliti menyampaikan judul materi dan tujuan pembelajaran yang akan dipelajari dan menjelaskan tentang metode Role Playing.

Pada kegiatan inti di pertemuan I peneliti menjelaskan materi tentang memahami pentingnya semangat kerja dan peneliti menyusun atau menyiapkan skenario yang akan ditampilkan dan menyampaikan materi pembelajaran setelah itu peneliti membagikan siswa dalam beberapa kelompok Siswa diarahkan untuk bermain peran sesuai dengan perannya masing-masing dan setiap kelompok masing-masing memperhatikan dan mengamati skenario yang sedang di mainkan, Siswa memainkan perannya didepan kelas

$\begin{array}{rrr}\text { Pada } & \text { kegiatan } & \text { akhir peneliti } \\ \text { bersama } & \text { siswa } & \text { memberikan }\end{array}$ kesimpulan terhadap materi yang telah dipelajari dan mengakhiri pelajaran denggan berdoa menurut agama dan kepercayaan masing-masing serta mengucapkan salam.

Di akhir siklus II pertemuan III merupakan akhir dari siklus pertama, peneliti mengulang kembali sedikit dari materi yang diberikan peneliti pada pertemuan pertama dan kedua, tentang pengertian mengenal jenis pekerjaan, kemudian peneliti mengadakan tes tertulis yang akan diberikan kepada siswa. Soal yang digunakan pada tes tersebut berupa soal isian. Pada saat tes berlangsung, siswa tidak diperbolehkan kerja sama. hasil tes dikumpulkan kemudian peneliti bersama siswa membahas soal tes tersebut bersama-sama. Adapun hasil belajar yang diperoleh dari siklus II yaitu rata-rata nilai siswa $79,67 \%$, siswa yang tuntas sebanyak 20 orang dengan persentase $64,51 \%$ dan siswa yang tidak tuntas sebanyak 11 orang dengan persentase $35,48 \%$.

\section{3) Observasi}

Observasi ini dilaksanakan bersamaan dengan proses belajar mengajar pada siklus II. Adapun hasil yang diperoleh secara rinci dari setiap aspek penilaian yaitu: pada siklus II pertemuan I siswa yang perhatian ketika proses pelajaran berlangsung mereka mendengarkan penjelasan guru yakni $70 \%$ dengan kategori baik, siswa yang memiliki keaktifan seperti bertanya materi yang dijelaskan dan menjawab hasil pembelajaran, yakni $71 \%$ dengan kategori baik kemudian siswa yang bekerjasama dengan baik dalam bertukar pendapat dalam mengerjakan dan menjawab soal yakni $72 \%$ dengan kategori baik dan siswa yang memiliki pemahaman dalam menanggapi hasil pembelajaran yakni $71 \%$ dengan kategori baik. jadi perolehan persentase keseluruhan kelas aktivitas siswa yaitu $71 \%$.

Pada pertemuan II hasil yang diperoleh secara rinci dari setiap aspek penilaian yaitu siswa yang perhatian ketika proses pelajaran berlangsung mereka mendengarkan penjelasan guru yakni $75 \%$ baik siswa yang memiliki keaktifan seperti bertanya tentang materi yang dijelaskan dan menjawab hasil pembelajaran yakni $77 \%$ dengan kategori cukup kemudian siswa yang bekerjasama dengan baik dalam bertukar pendapat dalam mengerjakan dan menjawab soal yakni $72 \%$ dengan kategori cukup, dan siswa yang memiliki pemahaman dalam menanggapi hasil pembelajaran yakni $75 \%$ dengan kategori baik. jadi perolehan persentase keseluruhan kelas yaitu $69 \%$.

\section{4) Refleksi}

Berdasarkan hasil pembelajaran siklus II yang telah dilaksanakan dengan penerapan metode Role Playing maka di paparkan sebagai berikut, Berdasarkan hasil tes belajar siswa yang mengalami ketuntasan ada 20 siswa dengan persentase $64,51 \%$ sedangkan 11 siswa lainnya tidak tuntas dengan persentase $35,48 \%$. 
Berdasarkan hasil wawancara dengan 20 siswa ada 16 siswa yang menyukai terkait dengan aspek siswa yang menyukai pelajaran IPS dengan menggunakan metode Role Playing dan 4 siswanya lagi tidak menyukai pelajaran IPS dengan menggunakan metode Role Playing. siswa yang mengalami kesulitan saat belajar IPS dengan menggunakan metode Role Playing ada 8 siswa sedangkan 12 siswanya lagi tidak mengalami kesulitan pada saat belajar IPS dengan menggunakan metode Role Playing, Siswa yang menyukai metode Role Playing ada 11 siswa sedangkan 9 siswanya lagi tidak menyukai metode Role Playing, dan siswa yang menyukai cara guru mengajar IPS ada 20 siswa.

Berdasarkan hasil observasi selama proses pembelajaran terdapat siswa memperhatikan saat peneliti menjelaskan materi pembelajaran namun masih dalam bimbingan peneliti dan sudah mulai berani dalam bertanya. Berdasarkan hasil telaah di atas maka peneliti memutuskan untuk melanjutkan pada siklus III.

\section{Hasil Penelitian Siklus III}

Siklus III tediri dari 3x pertemuan dalam kegiatan pembelajaran. Pada pertemuan pertama dan kedua adalah pelaksanaan kegiatan pembelajaran dengan menggunakan metode Role Playing materi mengenal kegiatan jual beli. Adapun tahapan pelaksanaannya sebagai berikut:

\section{1) Perencanaan}

Pada tahapan perencanaan pada siklus III peneliti menyusun serta mempersiapkan instrumen-instrumen penelitian, yaitu:

Peneliti menyususn Rencana Pelaksanaan Pembelajaran (RPP) sesuai dengan materi dan metode yang digunakan yang diajarkan dan menyiapkan media pembelajaran serta peneliti juga menyiapkan lembar observasi untuk melihat proses pembelajaran selama pembelajaran berlangsung dan membuat lembar soal pembelajaran yang berupa tes tertulis.

\section{2) Pelaksanaan}

Pelaksanaan kegiatan belajar mengajar pada siklus III dilaksanakan pada hari Selasa tanggal 16 April 2019 pertemuan I, Kamis 18 April 2019 pada jam pertama pertemuan II, Sabtu tanggal 20 April 2019 pertemuan III di kelas III SDN 027 Samarinda Ulu.

Pertemuan I tanggal 16 april 2019 Pada kegiatan awal peneliti mengucapkan salam dan mengajak siswa berdoa menurut agama kepercayaan masing-masing dan setelah itu peneliti mengecek kehadiran siswa. Setelah itu peneliti menyampaikan judul materi dan tujuan pembelajaran yang akan dipelajari. Sebelum pelajaran dimulai peneliti memotivasi siswa untuk tenang dan memperhatikan pelajaran yang disampaikan peneliti, dan peneliti melakukan apersepsi dengan mengajukan berbagai pertanyaan tentang kegiatan jual beli.

Pada kegiatan inti di pertemuan I peneliti menjelaskan materi tentang mengenal kegiatan jual beli dan peneliti menyusun atau menyiapkan skenario yang akan ditampilkan dan menyampaikan materi pembelajaran setelah itu peneliti membagikan siswa dalam beberapa kelompok Siswa diarahkan untuk bermain peran sesuai dengan perannya masing-masing dan setiap kelompok masing-masing memperhatikan dan mengamati skenario yang sedang di mainkan, Siswa memainkan perannya didepan kelas.

Pada kegiatan akhir peneliti bersama siswa memberikan kesimpulan terhadap materi yang telah dipelajari dan mengakhiri pelajaran denggan berdoa menurut agama dan kepercayaan masing-masing serta mengucapkan salam.

Pertemuan II tanggal 18 april 2019 Pada kegiatan awal peneliti mengucapkan salam dan mengajak siswa berdoa menurut agama kepercayaan masing-masing dan setelah itu peneliti mengecek kehadiran siswa. Setelah itu peneliti menyampaikan judul materi dan tujuan pembelajaran yang akan dipelajari. Sebelum pelajaran dimulai peneliti memotivasi siswa untuk tenang dan memperhatikan pelajaran yang disampaikan peneliti, dan peneliti melakukan apersepsi dengan 
mengajukan berbagai pertanyaan tentang kegiatan jual beli.

Pada kegiatan inti di pertemuan I peneliti menjelaskan materi tentang mengenal kegiatan jual beli dan peneliti menyususn atau menyiapkan skenario yang akan ditampilkan dan menyampaikan materi pembelajaran setelah itu peneliti membagikan siswa dalam beberapa kelompok Siswa diarahkan untuk bermain peran sesuai dengan perannya masing-masing dan setiap kelompok masing-masing memperhatikan dan mengamati skenario yang sedang di mainkan, Siswa memainkan perannya didepan kelas.

Pada kegiatan akhir peneliti bersama siswa memberikan kesimpulan terhadap materi yang telah dipelajari dan mengakhiri pelajaran denggan berdoa menurut agama dan kepercayaan masing-masing serta mengucapkan salam.

Di akhir siklus III pertemuan III merupakan akhir dari siklus III, peneliti mengulang kembali sedikit dari materi yang diberikan peneliti pada pertemuan pertama dan kedua, tentang pengertian mengenal kegiatan jual beli, kemudian peneliti mengadakan tes tertulis yang akan diberikan kepada siswa. Soal yang digunakan pada tes tersebut berupa soal Isian. Pada saat tes berlangsung, siswa tidak diperbolehkan kerja sama. Hasil tes dikumpulkan kemudian peneliti bersama siswa membahas soal tes tersebut bersama-sama. Adapun Hasil belajar yang diperoleh dari siklus III yaitu rata-rata nilai siswa $93,22 \%$ dimana semua siswa didalam kelas mengalami ketuntasan dengan persentase nilai $100 \%$. Berdasarkan perolehan data yang didapatkan pada siklus III, hasil belajar IPS sudah mencapai kriteria sangat baik. Untuk itu peneliti memutuskan untuk menghentikan sampai siklus III.

\section{3) Observasi}

Observasi ini dilaksanakan
bersamaan dengan proses belajar
mengajar pada siklus I. Adapun hasil
yang diperoleh secara rinci dari setiap
aspek penilaian yaitu:
Pada siklus I pertemuan I siswa
yang perhatian ketika proses pelajaran

berlangsung mereka mendengarkan penjelasan guru yakni $89 \%$ dengan kategori sangat baik, siswa yang memiliki keaktifan seperti bertanya materi yang dijelaskan dan menjawab hasil pembelajaran, yakni $88 \%$ dengan kategori sangat baik, kemudian siswa yang bekerjasama dengan baik dalam bertukar pendapat dalam mengerjakan dan menjawab soal yakni $83 \%$ dengan kategori sangat baik dan siswa yang memiliki pemahaman dalam menanggapi hasil pembelajaran yakni 90\% dengan kategori sangat baik. jadi perolehan persentase keseluruhan kelas aktivitas siswa yaitu $89 \%$.

Pada pertemuan II hasil yang diperoleh secara rinci dari setiap aspek penilaian yaitu siswa yang perhatian ketika proses pelajaran berlangsung mereka mendengarkan penjelasan guru yakni 93\% dengan kategori sangat baik siswa yang memiliki keaktifan seperti bertanya tentang materi yang dijelaskan dan menjawab hasil pembelajaran yakni 94\% dengan kategori sangat baik, kemudian siswa yang bekerjasama dengan baik dalam bertukar pendapat dalam mengerjakan dan menjawab soal yakni $90 \%$ dengan kategori sangat baik, dan siswa yang memiliki pemahaman dalam menanggapi hasil pembelajaran yakni $92 \%$ dengan kategori sangat baik. jadi perolehan persentase keseluruhan kelas yaitu $92 \%$.

Adanya peningkatan aktivitas belajar siswa yang dapat dilihat dari persentase aktivitas belajar siswa setiap siklusnya. Persentase pada siklus I pertemuan I yaitu $56 \%$, pertemuan II yaitu $69 \%$. Persentase pada siklus II Pertemuan I yaitu $71 \%$, pertemuan II yaitu $75 \%$. Persentase pada siklus III Pertemuan I yaitu $89 \%$, pertemuan II yaitu 92\%. Sehingga dapat diketahui persentase peningkatan aktivitas belajar siswa dari siklus I pertemuan I ke pertemuan II sebesar $13 \%$, siklus II pertemuan I ke pertemuan II 4\%, siklus III pertemuan I ke pertemuan II sebesar $3 \%$.

\section{4) Refleksi}

Berdasarkan hasil pembelajaran siklus III yang telah dilaksanakan dengan penerapan metode Role Playing 
maka di paparkan sebagai berikut, Berdasarkan hasil tes belajar siswa yang mengalami ketuntasan dimana semua siswa didalam kelas sudah mencapai indikator keberhasilan yaitu 75 dengan persentase $100 \%$

Berdasarkan hasil wawancara dengan 20 siswa dimana 20 siswa menyukai terkait dengan aspek siswa yang menyukai pelajaran IPS dengan menggunakan metode Role Playing. siswa yang mengalami kesulitan saat belajar IPS dengan menggunakan metode Role Playing ada 3 siswa sedangkan 17 siswanya lagi tidak mengalami kesulitan pada saat belajar IPS dengan menggunakan metode Role Playing, siswa yang menyukai metode Role Playing ada 20 siswa, dan siswa yang menyukai cara guru mengajar IPS 20 siswa.

Berdasarkan hasil observasi selama proses pembelajaran siswa sudah aktif dalam pembelajaran dimana siswa sudah berani dalam hal bertanya dan memperhatikan pada saat peneliti menjelaskan materi

Hal ini dapat diketahui dari hasil pra siklus mencapai ketuntasan belajar $40 \%$ dengan nilai rata-rata 60,80 dan pada selanjutnya siklus I ketuntasan belajar siswa mencapai 48,38\% dengan nilai rata-rata 72,25 rata 79,67 dan pada siklus II nilai hasil belajar siswa meningkat menjadi $64,51 \%$ dengan nilai rata-rata 79,67 dan pada siklus III nilai hasil belajar siswa meningkat menjadi $100 \%$ dengan nilai rata-rata 93,22

\section{PEMBAHASAN}

Hasil observasi aktivitas siswa pada aspek perhatian pada siklus I pertemuan I, siswa ketika proses pelajaran berlangsung mereka mendengarkan penjelasan guru dengan hasil persentase $57 \%$ termasuk kategori sangat kurang pada aspek keaktifan pada siklus I pertemuan I bahwa keaktifan siswa seperti bertanya tentang materi yang dijelaskan dan menjawab hasil pembelajaran dengan persentase $52 \%$ termasuk kategori sangat kurang dan pada aspek kerjasama pada siklus I pertemuan I kerjasama seperti siswa mampu bekerjasama dengan baik dalam bertukar pandapat dalam mengerjakan dan menjawab soal dengan hasil persentase 55\% termasuk kategori sangat kurang aspek pemahaman pada siklus I pertemuan I Aspek pemahaman seperti siswa yang memiliki pemahaman dalam menanggapi hasil pembelajaran dengan persentase $61 \%$ dengan kategori kurang hal ini disebabkan masih ada sebagian siswa yang perhatiannya kurang karena sibuk bermain dengan temannya dan juga kurangnya penguasaan kelas oleh peneliti. Pada pertemuan II aspek perhatian siswa pada saat proses pembelajaran dengan persentase $72 \%$ termasuk kategori cukup aspek keaktifan seperti bertanya dan menjawab dengan persentase $52 \%$ dengan kategori kurang, dan pada aspek kerjasama dalam kerja kelompok dan bertukar pendapat dengan persentase $65 \%$ termasuk kategori kurang dan pada aspek pemahaman dalam menanggapi hasil pembelajaran dengan hasil persentase $70 \%$ dengan kategori cukup, pada siklus I ini siswa bermain peran sesuai dengan materi yang diberikan yaitu materi jenis-jenis pekerjaan namun siswa masi malu dalam bermain perannya.

Hasil observasi siklus II pertemuan I siswa sudah mulai ada perubahan diamana pada siklus sebelumnya siswa masi malu tidak memperhatikan guru dan sibuk dengan temannya dan kurangnya penguasaan kelas oleh guru tetapi pada pertemuan II mereka mulai fokus dan mulai berani dalam hal bertanya dan memberikan pendapat namun masi dalam pengawasan guru. Dilihat dari aspek perhatian mengalami peningkatan dengan persentase $70 \%$ termasuk kategori cukup pada aspek keaktifan mengalami peningkatan dengan persentase $71 \%$ termasuk kategori cukup, dan pada aspek kerjasama dengan persentase $72 \%$ termasuk kategori cukup sedangkan pada aspek pemahaman dengan persentase $71 \%$ dengan kategori cukup. Pada pertemuan II aspek perhatian dengan nilai persentase $75 \%$ dengan kategori cukup, aspek keaktifan dengan nilai persentase $77 \%$, dan pada aspek kerjasama dengan nilai persentase $74 \%$ dengan kategori cukup, hal ini ini disebabkan siswa sudah mulai mendengarkan penjelasan dan sudah berani dalam bermain peran didepan kelas, dalam siklus I ini siswa bermain peran sesuai dengan materi yang peneliti berikan yaitu semangat kerja dimana siswa 
bermain peran dengan materi semangat kerja di dalam kelas

Hasil observasi pada siklus III ada peningkatan yang sangat drastis, hal ini karena peneliti lebih tegas lagi dalam penguasaan kelas dan dalam menjelaskan materi yang diberikan sehingga siswa tidak lagi bermain dan sibuk sendiri ketika proses pembelajaran berlangsung karena dengan menerapkan metode Role Playing ini juga membawa suasana bermain sambil belajar sehingga mereka terfokus pada pembelajaran. Pada siklus III ini siswa bermain peran dengan materi kegiatan jual beli dimana siswa akan melakukan kegiatan jual beli dalam kelas, pada tahap ini siswa sudah tidak lagi malu dalam berdrama. Pada aspek perhatian pertemuan I nila persentase mencapai $89 \%$ termasuk kategori baik meningkat pada siklus II dengan nilai persentase $93 \%$ dengan kategori sangat baik, pada aspek keaktifan pertemuan I nilai persentase $88 \%$ meningkat pada pertemuan II dengan nilai persentase $94 \%$ dengan kategori sangat baik, dan pada aspek kerja sama nilai persentase siswa pada pertemuan I $83 \%$ meningkat pada pertemuan II dengan nilai persentase $90 \%$, kemudian pada aspek pemahaman pertemuan I dengan nilai persentase $90 \%$ meningkat pada pertemuan II dengan nilai persentase $92 \%$

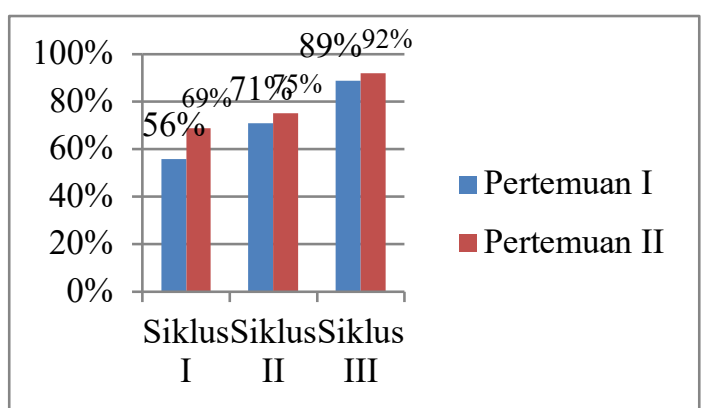

Gambar 1 : Diagram Perbandingan Hasil Aktivitas Siswa Siklus I,II, III

Hasil observasi siklus I sampai III mengalami peningkatan, hal ini membungktikan bahwa penelitian dengan menggunakan metode Role Playing telah berhasil. Pada siklus I pertemuan I 56\% termasuk kategori kurang dan pertemuan II $69 \%$ dengan kategori kurang, dan pada siklus II pertemuan I 71\% dengan kategori cukup lemudian pada pertemuan II $75 \%$ dengan kategori cukup sedangkan pada siklus III pertemuan I 89\% dengan kategori baik dan pada pertemuan II $92 \%$ dengan kategori sangat baikk

Dari data hasil belajar siswa pada siklus I dapat diketahui bahwa siswa yang tuntas sebanyak 15 siswa dengan rata-rata 72,25 dan persentase ketuntasan 48,38\% dan siswa yang tidak tuntas sebanyak 16 siswa dengan persentase $51,61 \%$ dapat disimpulkan bahwa belum mencapai indikator keberhasilan yaitu 75\%. Dari data nilai semester I (prasiklus) siswa kelas III yang peneliti peroleh dari wali kelas menunjukan bahwa proses pembelajaran menggunakan metode ceramah dan tanya jawab, karena metode ceramah hanya guru saja yang aktif dalam menyampaikan materi pembelajaran dan hal ini membuat siswa mudah bosan belajar karena tidak ada aktivitas siswa saat proses pembelajaran siswa hanya menjadi pendengar dan mengerjakan soal saja. Pada siklus I peneliti menerapkan metode Role Playing dan hal ini dapat memacu semangat siswa dalam pembelajaran sehingga siswa lebih aktif, terbukti pada siklus I membuktikan bahwa menggunakan media Role Playing cukup efektif untuk mata pembelajaran IPS pada materi yang diajarakan oleh peneliti

Hasil belajar pada siklus II siswa yang tuntas sebanyak 20 siswa dengan rata-rata 79,67 dan persentase ketuntasan 64,51\% dan siswa yang tidak tuntas sebanyak 13 siswa dengan persentase $35,48 \%$, dapat dikatakan bahwa pada siklus II belum mencapai indikator keberhasilan yaitu $75 \%$. namun hal ini juga menunjukan bahwa pada siklus II hasil belajar mengalami peningkatan dari nilai persentase ketuntasan prasiklus sebesar $40 \%$ menjadi $48,38 \%$ pada siklus I, dan meningkat lagi pada siklus II yaitu $64,51 \%$.

Hal ini disebabkan karena siswa sudah mulai paham dalam menggunakan metode Role Playing pada siklus II. Pada siklus II respon siswa dari hasil wawancara yang dilakukan oleh peneliti sangat bagus dan siswa suka dengan penerapan metode Role Playing, siswa menganggap lebih mudah belajar dengan menggunakan metode Role Playing.

Dari hasil belajar pada siklus III dimana semua siswa didalam kelas telah mencapai rata-rata 93,22 dan persentase ketuntasan yaitu $100 \%$ dengan indikator 
keberhasilan sebesar 75\%. Maka dapat dikatakan bahwa penelitian tindakan kelas ini dinyatakan berhasil karena terjadi peningkatan belajar dari prasiklus dengan persentase ketuntasan $40 \%$ dan siklus I dengan persentase ketuntasan $48,38 \%$ sedangkan pada siklus II dengan persentase ketuntasan $64,51 \%$ menjadi $100 \%$ pada siklus III. Maka syarat keajegan data dalam penelitian tindakan kelas telah terpenuhi, oleh karena itu penelitian ini di hentikan sampai siklus III.

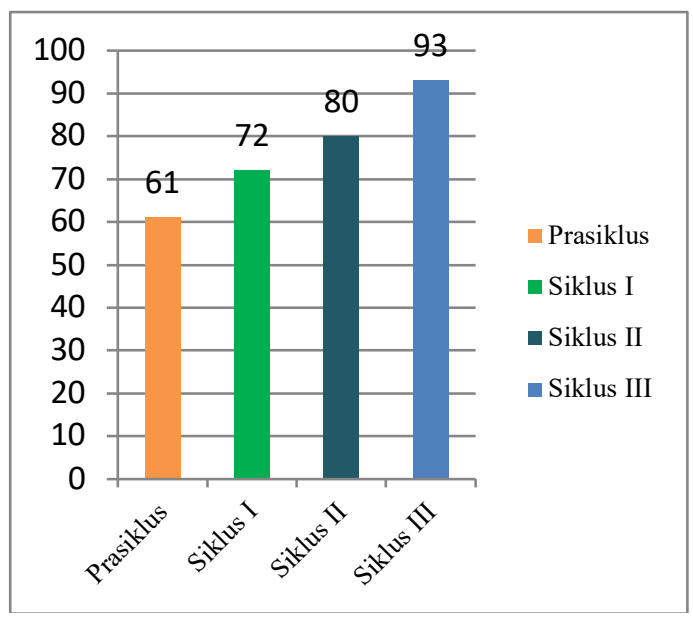

Gambar 2 : Diagram Perbandingan Nilai Rata-rata Hasil Belajar Prasiklus, Siklus I, Siklus II, Siklus III

Hasil data tersebut didukung dengan data wawancara pada siklus I, siklus II, dan siklus III di SDN 027 Samarinda Ulu Tahun Pembelajaran 2018/2019 dapat kita lihat siswa yang menyukai pelajaran IPS dengan menggunakan metode Role Playing pada siklus I ada 9 siswa dan yang tidak menyukai ada 11 siswa dan pada siklus II menjadi 19 siswa yang menyukai sedangkan yang tidak menyukai menjadi 4 siswa, pada siklus III siswa yang menyukai pelajaran IPS menggunakan metode Role Playing menjadi 20 siswa.

Hasil wawancara siswa terkait siswa yang mengalami kesulitan saat belajar IPS dengan menggunakan metode Role Playing pada siklus I yaitu 19 siswa dan yang tidak merasa kesulitan hanya 1 siswa kemudian pada siklus II siswa yang mengalami kesulitan belajar IPS ada 8 siswa dan 12 siswa nya lagi tidak merasa kesulitan saat belajar IPS, kemudian pada siklus III hanya 3 siswa saja yang merasa kesulitan saat belajar IPS sedangkan 17 siswa lainnya tidak merasa kesulitan pada saat belajar IPS menggunakan metode Role Playing.

Hasil wawancara terkait dengan siswa yang menyukai metode pembelajaran Role Playing pada siklus I ada 6 siswa sedangkan yang tidak menyukai ada 14 siswa, kemudian pada siklus II siswa yang menyukai metode Role Playing ada 11 siswa sedangkan yang tidak menyukai ada 9 siswa, kemudian pada siklus III siswa yang menyukai metode pembelajaran Role Playing ada 20 siswa.

Hasil wawancara dengan siswa terkait dengan siswa yang menyukai cara guru mengajar IPS dikelas pada siklus I ada 18 siswa dan 2 siswa lainnya tidak menyukai cara guru mengajar IPS dikelas, kemudian pada siklus II siswa yang menyukai cara guru mengajar mencapai 20 siswa dan pada siklus III juga 20 siswa.

Dari hasil triangulasi menunjukan bahwa observasi siswa pada akhir penelitian $92 \%$ siswa aktif dalam pembelajaran hal ini didukung dengan data wawancara yang dilaksanakan peneliti. Dari hasil wawancara $100 \%$ siswa menyukai pembelajaran dengan metode Role Playing. demikian pula bila dibandingkan dengan tes hasil belajar yang menunjukan peningkatan sampai akhir siklus.

Ketuntasan belajar siswa setiap siklusnya mengalami peningkatan hal ini sejalan dengan hasil observasi aktivitas siswa juga mengalami peningkatan di setiap siklusnya. Demikian juga hasil wawancara semua siswa sangat menyukai metode Role Playing untuk meningkatkan hasil belajar IPS

Dengan demikian syarat terjadinya keajegan dalam penelitian dalam penelitian tindakan kelas terpenuhi sesuai dengan pendapat Sugiyono (2015) yang menyatakan bila pengujian pada siklus pertama belum berhasil, maka setelah dilakukan refleksi, selanjutnya perencanaan diperbaiki, dan dilakukan pengujian pada siklus ke dua. Bila pengujian pada siklus ke dua telah berhasil, maka diuji konsistensinya pada siklus ketiga. Bila hasil pengujian tindakan pada siklus kedua dan ketiga tidak berbeda, maka pengujian tindakan dapat diakhiri. Oleh karena itu penelitian ini dihentikan sampai siklus III saja. 
Hasil penelitian tersebut sesuai yang dilakukan oleh Rizkia (2015) yang berjudul "Penerapan Metode Role Playing" untuk meningkatkan hasil belajar IPS Pada Siswa Kelas V SD Negeri 2 Kecemen Manisrenggo Klaten Jawa Tengah". Hasil penelitian menunjukan adanya peningkatan hasil belajar IPS dengan menggunakan metode Role Playing. Begitu pula dengan penelitian yang dilakukan Silvia (2016) dengan judul "Penerapan metode Role Playing untuk meningkatkan hasil belajar IPS peserta didik kelas V MI Al Huda Tumpang Talun Blitar". Hasil belajar yang diperoleh siswa kelas V mata pelajaran IPS MI Al Huda Tumpang Talun Blitar dapat dilihat Selain dari meningkatnya hasil belajar keaktifan siswa juga meningkat. Sedangkan penelitian yang dilakukan oleh peneliti untuk meningkatkan hasil belajar IPS kelas III di SDN 027 Samarinda Ulu Tahun Pembelajaran 2018/2019 yang dilakukan peneliti dengan menggunakan metode Role Playing menunjukan hasil belajar mencapai $93 \%$. Hal ini menunjukan bahwa metode Role Playing dapat meningkatkan hasil belajar.

Hal ini sesuai dengan sependapat Hamdayana (2014) berpendapat bahwa bermain peran pada prinsipnya merupakan pembelajaran untuk membawakan peranperan yang ada dalam dunia nyata ke dalam suatu pertunjukan peran dalam kelas, yang kemudian dijadikan sebagai bahan perbaikan agar peserta didik memberikan penilaian terhadap pembelajaran yang telah dilaksanakan begitu pula dengan penelitian yang dilakukan oleh peneliti yang menerapkan metode bermain peran dalam penelitiannya, dimana siswa memainkan peran yang ada di dunia nyata dalam kelas.

Menurut Uno (2012) berpendapat bahwa dalam permainan Role Playing beberapa peran dapat mendorong siswa dalam menyampaikan perasaan serta mengarahkan pada kesadaran melalui keterlibatan langsung yang disertai suatu pemecahan pada situasi permasalahan kehidupan nyata. Dalam penelitian yang dilakukan oleh peneliti menunjukan bahwa siswa mampu mendorong siswa menyampaikan pendapat dan mampu berekspresi didepan kelas.

Demikian dapat disimpulkan bahwa metode Role Playing dapat meningkatkan hasil belajar siswa pada siswa kelas III SDN 027 Samarinda Ulu Tahun Pembelajaran 2018/2019

\section{KESIMPULAN}

Dari kegiatan belajar mengajar yang telah dilakukan selama tiga siklus dan berdasarkan hasil analisis pada pembahasan, dapat disimpulkan dengan menerapkan metode pembelajaran Role Playing dapat meningkatkan hasil belajar siswa, hal ini dapat dilihat dengan adanya peningkatan pada setiap siklusnya, yaitu siklus I dengan nilai rata-rata72,25 dan ketuntasan $48,38 \%$, pada siklus II dengan nilai rata-rata 79,67 dan ketuntasan $64,51 \%$. Pada siklus III dengan rata-rata 93,22 dan ketuntasan 100\%.

Dengan menggunakan metode pembelajaran Role Playing dapat meningkatkan aktivitas siswa dalam proses belajar mengajar, hal ini dapat dilihat nilai observasi siswa pada siklus I pertemuan I dengan nilai persentase $56 \%$ dan pertemuan II dengan nilai persentase $69 \%$ kemudian pada siklus II pertemuan I dengan nilai persentase $71 \%$ dan pertemuan II dengan nilai persentase $75 \%$ sedangkan pada siklus III pertemuan I dengan nilai persentase $89 \%$ pertemuan II dengan nilai persentase $92 \%$. dengan adanya peningkatan pada setiap siklusnya, dengan demikian dapat disimpulkan bahwa metode Role Playing dapat meningkatkan hasil belajar siswa menjadi asyik, nyaman, dan menyenangkan.

\section{DAFTAR PUSTAKA}

Abu Ahmadi, Widodo S. 2013. Psikologi Belajar. Jakarta: PT. Rineka Cipta.

Arikunto, S. (2010). Prosedur Penelitian Suatu Pendekatan Praktik. Jakarta: Rineka Cipta

Andayani. (2015). Problem dan Aksioma Metodologi Pembelajaran Bahasa Indonesia. Yogjakarta: Deepublish.

Arikunto, S. (2010). Prosedur Penelitian Suatu Pendekatan Praktik. Jakarta: Rineka Cipta

Arikunto, S. (2016) Penelitian Tindakan Kelas (6th ed). Jakarta: PT. Bumi Askara.

Aqib, Z. (2016). Penelitian Tindakan Kelas. Bandung: Yrama widya.

Arikunto, S. (2006). Prosedur Penelitian 
Suatu Pendekatan Praktik. Jakarta: Rineka Cipta.

Alwi, M. (2011). Belajar Menjadi Bahagia dan Sukses Sejati. Jakarta: Elex Media Komputindo.

Dimyati dan Mudjiono. (2010). Belajar dan Pembelajaran. Jakarta: Rineka Cipta.

Fathurrohman, M. (2017). Belajar dan Pembelajaran Modern Konsep Dasar, Inovasi dan Teori Pembelajaran. Yogjakarta: Garudhawaca.

Kunandar. (2013). Penelitian Tindakan Kelas. Jakarta: PT.Raja Grafindo Persada.

Musfiqon. (2012). Pengembangan Media dan Sumber Pembelajaran. Jakarta: Prestasi Pusaka Publisher.

Muliawan, J.U. (2018).Penelitian Tindakan Kelas (Classroom Action Reserrch). Yogyakarta: Gava Media

Nurdin, S. (2016). Kurikulum dan Pembelajaran (2nd ed), Jakarta: PT. Raja Grafindo Persada.

Hasdin. (2014). Penerapan Metode Bermain Peran Untuk Meningkatkan Hasil Belajar IPS Pada Pokok Bahasan Kegiatan Jual Beli di Kelas III SDN Simo Kecamatan Simpang Raya Kabupaten Banggai.

Rizkia. (2015). Penerapan Metode Role Playing Untuk Meningkatkan Hasil Belajar IPS Pada Siswa Kelas V SD Negeri 2 Kecamen Manisrenggo Klaten Jawa Tengah.

Rusman. (2017). Belajar dan Pembelajaran Berorientasi Standar Proses Pendidikan. Jakartak: Kencana.

Siska, Y. (2016). Konsep Dasar IPS. Yogjakarta: Garudhawaca.

Silvia, R. (2016). Penerapan Metode Role Playing Untuk Meningkatkan Hasil Belajar IPS Peserta Dididk Kelas V MI Al Huda Tumpang Talun Blitar.

Sudjana, N. (2017). Teori-Teori Hasil Belajar. Bandung: Rosda.

Susanto, A. (2013b). Teori Belajar dan Pembelajaran di Sekolah Dasar. Jakarta: Kencana.

Susanto, A. (2013a). Teori Belajar dan Pembelajaran di Sekolah Dasar. Jakarta: Kencana.

Syah, M. (2014). Psikologi Pendidikan. Bandung: PT.Remaja Rosdakarya.

Susanto, A. (2013). Teori Belajar dan
Pembelajaran di Sekolah Dasar. jakarta: Kencana.

Sugiyono. (2015). Metode Penelitian Kombinasi. Bandung: Ifabeta.

Uno H. B. (2012). Model Pembelajaran. Jakarta: Bumi Askara.

Uno, H. B. (2014). Model Pembelajaran Menciptakan Proses Bealajar Mengajar Yang Kreatif dan Efektif (10th ed). Jakarta: PT. Bumi Askara. 